\title{
Combined Treatment with Mild Heat, Manothermosonication and Pulsed Electric Fields Reduces Microbial Growth in Milk.
}

\author{
Rachel Halpin \\ Technological University Dublin, rachel.halpin@tudublin.ie \\ O. Cregenzán-Alberti \\ School of Agriculture and Food Science, University College Dublin \\ P. Whyte \\ School of Veterinary Medicine, University College Dublin
}

See next page for additional authors

Follow this and additional works at: https://arrow.tudublin.ie/schfsehart

Part of the Biochemistry, Biophysics, and Structural Biology Commons, and the Food Biotechnology Commons

\section{Recommended Citation}

Halpin, R. et al. (2013) Combined Treatment with Mild Heat, Manothermosonication and Pulsed Electric Fields Reduces Microbial Growth in Milk. Food Control, Volume 34, Issue 2, December 2013, Pages 364-371 DOI :10.1016/j.foodcont.2013.05.008

This Article is brought to you for free and open access by the School of Food Science and Environmental Health at ARROW@TU Dublin. It has been accepted for inclusion in Articles by an authorized administrator of ARROW@TU Dublin. For more information, please contact arrow.admin@tudublin.ie, aisling.coyne@tudublin.ie, gerard.connolly@tudublin.ie.

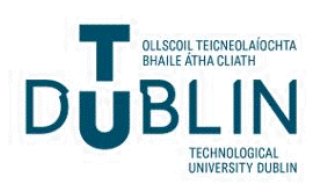




\section{Authors}

Rachel Halpin, O. Cregenzán-Alberti, P. Whyte, J.G Lyng, and F. Noci

This article is available at ARROW@TU Dublin: https://arrow.tudublin.ie/schfsehart/242 


\section{Combined treatment with mild heat,}

\section{2 manothermosonication and pulsed electric fields reduces}

\section{3 microbial growth in milk.}

$4 \quad$ Halpin, R.M. ${ }^{1 *}$, Cregenzán-Alberti, O. $^{1}$, Whyte, P. $^{2}$, Lyng, J.G. $^{1}$ and Noci, F. ${ }^{1 \S}$

$5{ }^{1}$ School of Agriculture and Food Science, University College Dublin, Ireland,

$6 \quad{ }^{2}$ School of Veterinary Medicine, University College Dublin. Ireland.

7

$8 \S$ Current address: Hotel School, Galway-Mayo Institute of Technology, Galway Campus,

9 Dublin Road, Galway, Ireland.

10

$11 *$ Corresponding author: Dr. Rachel Halpin.

12 Postal address: School of Agriculture and Food Science, University College Dublin, Belfield,

13 Dublin 4, Ireland.

14 Tel No.: 0035317162851

15 E-mail: rachel.halpin@ucd.ie

16

17

18

19 


\section{Abstract}

22 In recent years, there has been considerable interest in non-thermal milk processing. The 23 objective of the present study was to assess the efficacy of two non-thermal technologies 24 (manothermosonication; MTS, and pulsed electric fields; PEF) in comparison to thermal pasteurisation, by assessing the microbiological quality of each of these milk samples postprocessing. Homogenised milk was subjected to MTS (amplitude; $27.9 \mu \mathrm{m}$, pressure; 225 $\mathrm{kPa}$ ) at two temperatures $\left(37^{\circ} \mathrm{C}\right.$ or $\left.55^{\circ} \mathrm{C}\right)$, before being immediately treated with $\mathrm{PEF}$ (electric field strength; $32 \mathrm{kV} / \mathrm{cm}$, pulse width; $10 \mu \mathrm{s}$, frequency; $320 \mathrm{~Hz}$ ). Thermal pasteurisation $\left(72^{\circ} \mathrm{C}, 20 \mathrm{~s}\right)$ was included as a control treatment. Microbial content of each milk sample was monitored over a 21-day period. It was determined that milks treated with $\mathrm{MTS} / \mathrm{PEF}$ at $37^{\circ} \mathrm{C}$ and $55^{\circ} \mathrm{C}$ contained lower microbial levels for a certain duration, but after 14 days milk which had been pasteurised by conventional methods contained significantly ( $P$ $<0.05)$ less microorganisms. However, milks treated with MTS/PEF contained significantly $(P<0.05)$ fewer microorganisms than raw milk at each time point. Although not as effective as thermal pasteurisation, the present study demonstrates the ability of MTS/PEF treatment to reduce microbial content of milk, while avoiding prolonged heat exposure to temperatures such as those used during conventional (thermal) pasteurisation.

Keywords: non-thermal processing, manothermosonication, pulsed electric fields, milk, microbiological quality. 


\section{Introduction}

Milk is a nutritious medium which presents an ideal environment for the growth of many pathogenic and spoilage microorganisms (Pereda et al., 2009). Consequently, milk has a relatively short shelf-life. Milk is usually processed by heat treatment in order to prolong its shelf-life, and although these thermal treatments destroy microorganisms, they can also have detrimental effects on the nutritional and organoleptic properties of milk (Odriozola-Serrano, Bendicho-Porta, \& Martin-Belloso, 2006). The demand by consumers for fresh, safe foods with favourable sensory properties while also having an adequate shelf-life is a difficult need for the food industry to meet while using thermal treatment (Pereda et al., 2009). Thus, in recent years there has been considerable interest in the non-thermal processing of foods and beverages.

Non-thermal processing technologies require significantly less heat than thermal processing, or in some cases no heat at all, and are consequently less energy-intensive and more environmentally friendly than thermal methods (Piyasena, Mohareb, \& McKellar, 2003). In addition, foods/beverages subjected to non-thermal processing are regarded as being fresh-like, with minimal loss of colour, flavour and nutrients (Bermudez-Aguirre, Mawson, Versteeg, \& Barbosa-Canovas, 2009). Examples of such non-thermal processes include microfiltration, pulsed-light inactivation and high hydrostatic pressure. Two nonthermal processing methods of particular relevance to the present study are ultrasonication and pulsed electric field technology.

Ultrasound (US) is defined as sound waves with frequencies above the threshold of human hearing (>16 kHz) (Manas \& Pagan, 2005), and this technology can be used to damage or disrupt microbial cells (Dolatowski, Stadnik, \& Stasiak, 2007). During sonication, a sonic wave meets a liquid medium and regions of alternating compression and expansion 
are created. These regions of pressure change cause cavitation, and bubbles are formed in the medium. During the expansion cycle, the bubbles expand, and a point is reached where the bubble implodes and rapid condensation occurs. The condensed molecules collide violently and shock waves are created, which are of very high pressures and temperatures of up to 50MPa and $5500^{\circ} \mathrm{C}$, respectively (Dolatowski, Stadnik, \& Stasiak, 2007). These resulting changes in pressure and 'hot zones' can kill bacteria, with the former being the main contributor to microbial inactivation (Piyasena, Mohareb, \& McKellar, 2003). In order to increase antimicrobial efficacy, sonication can be combined with heat (thermosonication; TS), pressure (manosonication; MS), or heat and pressure (manothermosonication; MTS). However, the effectiveness of ultrasound is dependent on the type of microorganism targeted, the amplitude of the ultrasonic waves, treatment time and the volume and composition of the food being treated (Dolatowski, Stadnik, \& Stasiak, 2007). With regard to microbial susceptibility, Gram positive bacteria are generally more sensitive than Gram negative microorganisms, and spores are considered to be more resistant to treatment with ultrasound than vegetative cells (Burgos, 1998).

Another non-thermal inactivation method which is gaining popularity in terms of commercial interest is pulsed electric field (PEF) technology (Devlieghere, Vermeiren, \& Debevere, 2004). This method is based on a pulsing power delivered to a food/beverage placed between a set of electrodes within a chamber. Essentially, a series of high voltage pulses are applied between the set of electrodes, which causes disruption to and subsequent permeabilisation of microbial cell membranes; a process known as 'electroporation' (Hamilton, \& Sale, 1967, Devlieghere, Vermeiren, \& Debevere, 2004; Walkling-Ribeiro et al., 2009a). The electrical fields can be applied for durations varying from nanoseconds to microseconds, and depending on the electrical field strength, pulse duration and pulse number, permeabilisation can be either reversible or irreversible (Aronsson, Borch, Stenlof, 
93 \& Ronner, 2004). The effectiveness of PEF treatment for the purpose of microbial

94

95 inactivation is a reflection of these parameters (i.e. EFS and overall treatment time). In general, Gram-positive bacteria are more resistant to treatment with PEF than Gram negative bacteria, while yeasts are more sensitive than bacteria (Devlieghere, Vermeiren, \& Debevere, 2004).

The objective of the present study was to compare the efficacy of MTS/PEF when applied at two temperatures $\left(37^{\circ} \mathrm{C}\right.$ and $\left.55^{\circ} \mathrm{C}\right)$ to thermal pasteurisation. After milk had been subjected to processing with MTS/PEF or high temperature short time (HTST) pasteurisation, specific microorganisms were monitored over a 21-day period, and comparisons made between the microbiological qualities of each milk sample after processing.

\section{Materials and Methods}

\subsection{Milk Sourcing and Preparation}

Fresh raw bovine milk from a bulk tank was obtained from Lyons Research Farm (Newcastle, Co. Dublin) and transported to the laboratories at UCD Dublin within 40 min. Three batches of raw whole milk were obtained on three separate occasions. Milk was stored at $4^{\circ} \mathrm{C}$ until required. On the same day as collection from the farm, milk was preheated to $55^{\circ} \mathrm{C}$ and homogenized at a total pressure of $21 \mathrm{MPa}$. A two-stage high-pressure homogenizer (Model No. Panda 2682, Niro Soavi, Parma, Italy) was used for this purpose, and pressures of $18 \mathrm{MPa}$ and 3MPa were applied in the primary and secondary stages, respectively. Milk was subsequently processed using non-thermal methods or conventional pasteurisation.

\subsection{Treatment of Milk with MTS/PEF}

Previous experiments in this laboratory examining the inhibitory effect of (i) MTS and (ii) PEF as individual treatments showed that optimal microbial inactivation levels were achieved 
using power levels of $27.9 \mu \mathrm{m}(225 \mathrm{kPa})$ and $32 \mathrm{kV} / \mathrm{cm}$ for MTS and PEF, respectively (data not shown). Thus, these were the power settings used in the present study. Other parameters applied were as follows: for MTS treatment, the frequency was set to $20 \mathrm{kHz}$, and the total pressure was $225 \mathrm{kPa}$, while for PEF the frequency was set at $320 \mathrm{kHz}$, and the pulse width was $10 \mu \mathrm{s}$.

A peristaltic pump (Masterflex ${ }^{\circledR}$ L/S ${ }^{\circledR}$, Model No. 77250-62, Cole-Parmer Instrumental Company, IL, USA) was used to pass milk through a submerged coil in a heated water bath so that the milk reached a temperature of $37^{\circ} \mathrm{C}$ or $55^{\circ} \mathrm{C}$ prior to entering the sonicators. This heating process was quite rapid, taking less than one or two minutes to reach $37^{\circ} \mathrm{C}$ or $55^{\circ} \mathrm{C}$, respectively. A flow rate of $160 \mathrm{ml} / \mathrm{min}$ was used. For MTS processing, two ultrasonic processors were employed (Model No. UIP 1000hd, Hielscher, Germany). These sonicators were connected in a row, and had an operational frequency of $20 \mathrm{kHz}$. Two sonotrodes (Model No. BS2d40, Hielscher), each of which had a $40 \mathrm{~mm}$ frontal face diameter were used. Also, boosters were used to strengthen the amplitude (Model No. B2-1.8, Hielscher). The volume of each sonication chamber was $168 \mathrm{ml}$, and the total residence time of milk within the chamber was determined to be on average 2.1 min; this duration was found to be adequate for microbial inactivation in preliminary studies carried out to optimise processing conditions (data not shown). In addition, the chambers of each sonicator were surrounded by jackets which contained flowing water so that the temperature within the chamber could be maintained at $37^{\circ} \mathrm{C}$ or $55^{\circ} \mathrm{C}$. The temperatures of the milk entering and leaving the sonicators were monitored using T-type thermocouples (Model No. SQ2020, Grant Instruments, Cambridge, UK).

Immediately following treatment with MTS, milk was subjected to PEF treatment. A continuous laboratory scale PEF unit (ELCRACK HVP 5, DIL, German Institute of Food Technologies, Quackenbruck, Germany) was used. The treatment module consisted of three 
co-linear treatment chambers with a refrigerated cooling module integrated; these cooling sections were present following the first and third chambers. Each chamber held two colinear stainless steel electrodes separated by a $5.0 \mathrm{~mm}$ gap, with the electrode diameter being $3.0 \mathrm{~mm}$, which resulted in a total treatment volume of $0.106 \mathrm{~cm}^{3}$. PEF treatment was applied using monopolar square-wave pulses (10 $\mu$ s pulse width, $320 \mathrm{~Hz}$ frequency). The EFS was $32 \mathrm{kV} / \mathrm{cm}$ and the total treatment time was determined to be $127 \mu \mathrm{s}$. The product temperature was recorded using thermocouples (Testo 925, type-K probe, Testo AG, Lenzkirch, Germany) both before and after the treatment module, and was never allowed to exceed $37^{\circ} \mathrm{C}$ or $55^{\circ} \mathrm{C}$ depending on the treatment being applied. Following treatment with MTS/PEF, milk was collected in a sterile glass bottle and stored at $4^{\circ} \mathrm{C}$ until required.

\subsection{Thermal Pasteurisation of Milk}

Raw, homogenised milk was thermally pasteurised using a tubular heat exchanger (Model

No. FT74 UHT/HTST Processing System, Armfield Technical Education Co. Ltd,

Ringwood, U.K.). Milk was heated at $72^{\circ} \mathrm{C}$ for 20 s. An attached cooling system ensured the temperature of the milk was below $10^{\circ} \mathrm{C}$ after treatment. Milk was collected in a sterile glass bottle, and stored at $4^{\circ} \mathrm{C}$ for microbial analysis for the duration of the microbiological assessment.

\subsection{Microbiological Analysis}

The microbial content of all milk samples (i.e. raw and post-processing with MTS/PEF or thermal pasteurisation) was monitored at defined time points (days $0,2,5,7,9,14,21$ ). The total viable count (TVC) was quantified by preparing decimal dilutions of each milk sample in sterile quarter-strength Ringer's solution (Oxoid, Basingstoke, U.K.). An aliquot (100 $\mu \mathrm{l})$ of appropriate dilutions was then spread-plated onto plate count agar (PCA; Scharlau, Barcelona, Spain) in duplicate, and plates were incubated at $37^{\circ} \mathrm{C}$ for 48 hours. The following microorganisms were also quantified: 
(a) Yeasts and moulds: on potato dextrose agar (PDA; Oxoid; Basingstoke, U.K.), incubated at $30^{\circ} \mathrm{C}$ for $48 \mathrm{~h}$.

(b) Staphylococcus aureus: on Baird Parker agar (BPA; Merck, Darmstadt, Germany), 

during each experiment and the average calculated $(n=3)$. For milk treated at $37^{\circ} \mathrm{C}$, milk entered the MTS chamber at $37^{\circ} \mathrm{C}\left( \pm 0^{\circ} \mathrm{C}\right)$ and left the MTS system at $36.5^{\circ} \mathrm{C}\left( \pm 0.5^{\circ} \mathrm{C}\right)$. The milk then cooled to $25.7^{\circ} \mathrm{C}\left( \pm 0.5^{\circ} \mathrm{C}\right)$ before entering the PEF system, and the average temperature post-PEF processing was $32.1^{\circ} \mathrm{C}\left( \pm 3^{\circ} \mathrm{C}\right)$. In the case of milk treated at $55^{\circ} \mathrm{C}$, milk entered the MTS system at this temperature $\left( \pm 0^{\circ} \mathrm{C}\right)$, and left the MTS chamber at $57^{\circ} \mathrm{C}$ $\left( \pm 0.4^{\circ} \mathrm{C}\right)$. The milk subsequently cooled, before entering the PEF system at a temperature of $40.5^{\circ} \mathrm{C}\left( \pm 0.4^{\circ} \mathrm{C}\right)$. Temperatures post-PEF treatments were found to be on average $32.1^{\circ} \mathrm{C}( \pm$ $\left.5.1^{\circ} \mathrm{C}\right)$

All processed milks (i.e. $37^{\circ} \mathrm{C}$ or $55^{\circ} \mathrm{C}$ MTS/PEF-treated and thermally pasteurised) significantly reduced the TVC of milk when compared to raw milk $(P<0.05)$ over the 21-day period (Figure 1). On days 5, 7 and 9 the TVC of milk treated at $37^{\circ} \mathrm{C}$ was not found to be significantly different from the TVC of milk that had undergone conventional pasteurisation $(P>0.05)$. However, after 21 days, the $37^{\circ} \mathrm{C}$ and $55^{\circ} \mathrm{C}$ MTS/PEF treatments were found to have a significantly higher TVC than milk that had been pasteurised using the HTST method $(P<0.05)$. The TVC of raw milk was found to be $c .2 \times 10^{8} \mathrm{CFU} / \mathrm{ml}$ after 21 days. The average TVC of milks treated at $37^{\circ} \mathrm{C}$ and $55^{\circ} \mathrm{C}$ after 21 days were found to be $9.34 \times 10^{6}$ and $6.58 \times 10^{6}$, respectively. These values were significantly $(P<0.05)$ higher than that of pasteurised milk $\left(1.26 \times 10^{2} \mathrm{CFU} / \mathrm{ml}\right)$. Nonetheless, both the $37^{\circ} \mathrm{C}$ and $55^{\circ} \mathrm{C} \mathrm{MTS} / \mathrm{PEF}$ treatments resulted in a $c .4$ log reduction of TVC when compared to raw milk after 21 days. However, thermal pasteurisation resulted in a log reduction of 6.8. Similarly, all treated milks contained a significantly $(P<0.05)$ lower number of yeasts and moulds than raw milk over the entire 21-day period (Figure 2). On average, raw milk treatments reduced the level of yeasts and moulds in the milk over the 21-day period. On 
days 2 and 5, no significant difference was found between any of the treatments at the 5\% significance level. On days 7 and 9, no significant difference was found between the $37^{\circ} \mathrm{C}$ MTS/PEF treatment and conventional pasteurisation $(P>0.05)$. By day 21 , thermally pasteurised milk was found to contain the least number of yeasts and moulds $(P<0.05)$.

With regard to $S$. aureus, raw milk generally contained a significantly higher level of this microorganism over the 21-day period than all processed milks (Figure 3). The average initial level of $S$. aureus in raw milk was determined to be $4.13 \times 10^{4} \mathrm{CFU} / \mathrm{ml}$, and this level reached $2.09 \times 10^{6} \mathrm{CFU} / \mathrm{ml}$ by day 21 , with all treatments significantly reducing the level of $S$. aureus in milk $(P<0.05)$. However, on day 21 the $37^{\circ} \mathrm{C}$ MTS/PEF treatment was found to have a similar level of $S$. aureus as raw milk. On day 0, pasteurisation reduced the amount of S. aureus by 3 log cycles when compared to raw milk, while treatment with MTS/PEF at $37^{\circ} \mathrm{C}$ and $55^{\circ} \mathrm{C}$ resulted in log reductions of 1.4 and 2.7 , respectively. On days $2,5,7$ and 9 , no significant differences were observed between the S. aureus content of all treated milk samples (i.e. MTS/PEF or pasteurised) at the 5\% significance level. On days 14 and 21, pasteurised milk was found to contain significantly lower levels of $S$. aureus than milks treated with $\mathrm{MTS} / \mathrm{PEF}$ at $37^{\circ} \mathrm{C}$ and $55^{\circ} \mathrm{C}$.

In the case of Enterobacteriaceae (Figure 4), raw milk contained greater levels of Enterobacteriaceae than all other milks $(P<0.05)$ at each of the time points examined. On days 0,2 and 9, no significant difference was observed between the milks treated with MTS/PEF at both temperatures (i.e. at $37^{\circ} \mathrm{C}$ and $55^{\circ} \mathrm{C}$ ). On days 5, 7, 14 and 21, no significant difference was observed between the Enterobacteriaceae content of milks treated with MTS/PEF at $37^{\circ} \mathrm{C}$ and conventional pasteurisation $(P<0.05)$. On day 21 , the level of Enterobacteriaceae in raw milk had reached $2.4 \times 10^{7} \mathrm{CFU} / \mathrm{ml}$, whereas the levels present in milks treated at $37^{\circ} \mathrm{C}$ and $55^{\circ} \mathrm{C}$ with $\mathrm{MTS} / \mathrm{PEF}$ were reduced by 4.4 and 4.1 log cycles, 
respectively. Thermal pasteurisation appeared to almost completely prevent growth of Enterobacteriaceae for the duration of the study.

Raw milk was also found to contain significantly more lactic acid bacteria (LAB) at each time point than any of the other processed milk samples $(P<0.05)$ (Figure 5). On days 2, 5 and 7, no significant difference $(P>0.05)$ was observed between any of the treatments, but on days 14 and 21, conventionally pasteurised milk contained less lactic acid bacteria than milk heated at $37^{\circ} \mathrm{C}$ and $55^{\circ} \mathrm{C}$ prior to $\mathrm{MTS} / \mathrm{PEF}$ treatment. By day 21 , raw milk was found to contain c. $5.4 \times 10^{7} \mathrm{CFU} / \mathrm{ml} \mathrm{LAB}$, while treatments where milk was heated to $37^{\circ} \mathrm{C}$ and $55^{\circ} \mathrm{C}$ before being subjected to MTS/PEF caused log reductions of 2.9 and 2, respectively, with conventional pasteurisation resulting in a log reduction of 5.4.

With the exception of days 9 and 14, raw milk was found to contain significantly more pseudomonads than all of the processed milk samples $(P<0.05)$ (Figure 6). Also, on days $0,2,5,7$ and 9, milk which had been treated at $55^{\circ} \mathrm{C}$ followed by MTS/PEF contained a similar level of pseudomonads to thermally pasteurised milk $(P>0.05)$. No significant difference was found between milks treated at $37^{\circ} \mathrm{C}$ and $55^{\circ} \mathrm{C}$ followed by MTS/PEF at any of the time points over the 21 days $(P<0.05)$. By day 21, the level of pseudomonads had reached $1 \times 10^{9} \mathrm{CFU} / \mathrm{ml}$, but treating milk by heating at $37^{\circ} \mathrm{C}$ and $55^{\circ} \mathrm{C}$ prior to $\mathrm{MTS} / \mathrm{PEF}$ resulted in log reductions of 1.9 and 1.8, respectively. However, thermal pasteurisation was found to show a substantially higher log reduction (6.6) in the level of pseudomonads in comparison to raw milk than all other treatments by day $21(P<0.05)$.

Finally, the levels of psychrotrophic bacteria in raw milk, MTS/PEF treated milk samples and pasteurised milk were measured at four time intervals over the 21-day period (Figure 7). As had been determined for all other microbial species examined throughout this study, raw milk was found to contain higher levels of psychrotrophs than milks which had been subjected to MTS/PEF or conventional pasteurisation. The average initial level of 
psychrotrophic bacteria from the three batches of raw milk was estimated to be $1.6 \times 10^{5}$

$266 \mathrm{CFU} / \mathrm{ml}$, and this level reached $7 \times 10^{7} \mathrm{CFU} / \mathrm{ml}$ by day 21 . Plate count results from day 0

267

268 showed there was a minimum of a 3.5 log reduction in the level of psychrotrophic bacteria in milk after treatment with MTS/PEF. On days 14 and 21, thermally pasteurised milk contained significantly lower levels of psychrotrophs than milks treated with MTS/PEF at either $37^{\circ} \mathrm{C}$ or $55^{\circ} \mathrm{C}(P<0.05)$.

\section{Discussion}

Raw milk contains a wide range of microorganisms including yeasts and moulds, both Gram positive and Gram negative bacteria, and a range of bacterial spores (Shamsi, Versteeg, Sherkat, \& Wan, 2008). The present study has shown that combining two non-thermal technologies (i.e. MTS and PEF) can decrease the microbial populations of raw milk, and consequently improve the microbiological quality. A study by Noci et al. (2009) reported inactivation of Listeria innocua by up to $c .7$ log cycles following treatment with thermosoniaction immediately followed by pulsed electric fields. No other studies have been undertaken to assess the microbiological quality of milk following treatment with a combination of manothermosonication and pulsed electric fields. Thus, no direct comparisons can be made between the present study and other published studies. However, details of some studies which applied ultrasound and pulsed electric fields as separate entities for the purpose of microbial inactivation have been reported.

Milk processing by high intensity pulsed electric fields has been reviewed previously (Bendicho, Barbosa-Canovas, \& Martin, 2002), and many researchers have reported how PEF can be used specifically for microbial inactivation in milk (Odriozola-Serrano, Bendicho-Porta, \& Martin-Belloso, 2006; Cserhalmi, Sass-Kiss, Toth-Markus, \& Lechner, 2006; Craven et al., 2008; Shamsi, Versteeg, Sherkat, \& Wan, 2008; Sepulveda, GongoraNieto, Guerrero, \& Barbosa-Canovas, 2009; Walkling-Ribeiro, Rodriguez-Gonzalez, 
Jayaram, \& Griffiths, 2011). In addition, PEF is a popular method for extending the shelf-life of fruit juices (Walkling-Ribeiro et al., 2009a, 2009b, 2010; Yeom, Streaker, Zhang, \& Min, 2000) and fruit juice-milk based beverages (Walkling-Ribeiro et al., 2008; Sampedro et al., 2009; Salvia-Trujillo, Morales-de la Pena, Rojas-Grau, \& Martin-Belloso, 2011). Therefore, combining PEF with other non-thermal technologies could represent an alternative approach to improving microbiological quality and consequently prolonging the shelf-life of many beverages, both dairy and non-dairy based.

Under the experimental conditions used in the present study for MTS and PEF, the TVC values were reduced considerably following processing at both temperatures $\left(37^{\circ} \mathrm{C}\right.$ and $55^{\circ} \mathrm{C}$ ), producing milk with a similar TVC to that of conventionally pasteurised milk. A study by Villamiel and de Jong (2000) which assessed the total bacterial count of milk following treatment with ultrasound $(20 \mathrm{kHz})$ in a continuous-flow system reported reductions of 0.2 , 0.6 and $2.9 \log$ cycles following treatment with US at residence times of 34, 56 and 102 seconds, respectively, inside the treatment chamber. In addition, the temperatures reached during these treatments were $48.6^{\circ} \mathrm{C}, 62^{\circ} \mathrm{C}$ and $76^{\circ} \mathrm{C}$, respectively. These inactivation values are much lower than those of the present study, where only mild heat was applied during MTS/PEF treatment (i.e. $37^{\circ} \mathrm{C}$ and $55^{\circ} \mathrm{C}$ ). In the same study by Villamiel and de Jong (2000), milks which had been processed at $62^{\circ} \mathrm{C}$ in a continuous flow ultrasound system or in a conventional heating system were compared over a five day period. It was determined that the number of bacteria remained constant at c. $4 \log \mathrm{CFU} / \mathrm{ml}$ until the third day of storage, and then went on to reach c. $5 \log \mathrm{CFU} / \mathrm{ml}$ after five days, with the increase in total bacteria counts being similar for both US-treated milk and thermally treated milk. These values for inactivation are in contrast to those observed in the present study, where MTS/PEF processed milk treated at $37^{\circ} \mathrm{C}$ and $55^{\circ} \mathrm{C}$ had TVC levels of c. 1.8 and $2.7 \log \mathrm{CFU} / \mathrm{ml}$, respectively, 
seven days after treatment. This demonstrates the benefits of combining MTS with PEF so that higher levels of microbial inactivation can be achieved.

Another study by Chouliara, Georgogianni, Kanellopoulou, \& Kontominas (2010) examined TVC levels in full fat milk following treatment with US over an eight day period. Ultrasound was applied at $24 \mathrm{kHz}$ (amplitude was not specified) and after eight days, it was determined that raw milk contained $4.3 \log \mathrm{CFU} / \mathrm{ml}$, but values were reduced to 3.8, 3.1, 2.9 and $2.9 \log$ CFU/ml following 2, 4, 8 and 16 mins of sonication, respectively. Similar studies have also been conducted by Bermudez-Aguirre and co-workers where microbial levels of milk following treatment with US (Bermudez-Aguirre, Mawson, Versteeg, \& BarbosaCanovas, 2009) and PEF (Bermudez-Aguirre et al., 2011) were assessed. In one study, these authors examined the total mesophilic count of raw whole milk over a 16-day period (Bermudez-Aguirre, Mawson, Versteeg, \& Barbosa-Canovas, 2009). The mesophilic count was determined to be $4.7 \log \mathrm{CFU} / \mathrm{ml}$ on day 0 , and after treatment with US (24 kHz, 108 $\mu \mathrm{m}, 63^{\circ} \mathrm{C}, 30 \mathrm{~min}$ ) this was reduced to $c .2 \log \mathrm{CFU} / \mathrm{ml}$ and $<1 \log \mathrm{CFU} / \mathrm{ml}$ on days 0 and 16 , respectively. Thermally treated milk contained c. $5.8 \log \mathrm{CFU} / \mathrm{ml}$ after 16 days under refrigeration at $4^{\circ} \mathrm{C}$. In addition, these researchers applied ultrasound to milk at $36 \mu \mathrm{m}, 72$ $\mu \mathrm{m}, 108 \mu \mathrm{m}$ and $120 \mu \mathrm{m}$, and no more than 2 log cycles of mesophiles were detected over the 16-day period. However, it should be taken into consideration that milk was heated at $63^{\circ} \mathrm{C}$ for 30 min while being treated with ultrasound during these experiments. In the present study, ultrasound was applied for c. 2.1 mins, and milk was heated at $37^{\circ} \mathrm{C}$ or $55^{\circ} \mathrm{C}$. Immediately after processing (i.e. on day 0$)$, milks heated at these temperatures $\left(37^{\circ} \mathrm{C}, 55^{\circ} \mathrm{C}\right)$ during $\mathrm{MTS}$ treatment still yielded reductions of 2.6 and 3.6 log cycles, respectively, in spite of relatively mild and moderate heat treatments applied.

With regard to PEF, a shelf-life study by Odriozola-Serrano, Bendicho-Porta, \& Martin-Belloso (2006) reported a reduction of mesophilic bacteria of between 1 and $2 \log$ 
cycles in raw whole milk treated at $35.5 \mathrm{kV} / \mathrm{cm}$, temperature of $<40^{\circ} \mathrm{C}$ and pulse width of 7 $\mu$ s. A separate study by Bermudez-Aguirre et al. (2011) examined the effect of PEF (46.15 $\mathrm{kV} / \mathrm{cm}, 200 \mathrm{kHz}, 30$ pulses $\times 2 \mu$ s, flow rate $1 \mathrm{~L} / \mathrm{min}$ ) on microbial inactivation in whole fat milk. It was determined that mesophilic and psychrotophic bacteria were reduced by 0.4 and $0.8 \log$ cycles, respectively, after treatment with $\mathrm{PEF}$ at $40^{\circ} \mathrm{C}$. It was observed during this study that in general, mesophilic bacteria were more resistant than psychrotrophic bacteria to PEF thermal treatment, although inactivation of both of these types of microorganisms was not considered to be high. A shelf-life study carried out by Bermudez-Aguirre et al. (2011) showed that mesophiles grew rapidly during storage at $4^{\circ} \mathrm{C}$ in milk after treatment with PEF at $20^{\circ} \mathrm{C}, 30^{\circ} \mathrm{C}$ and $40^{\circ} \mathrm{C}$, with the level of mesophilic bacteria exceeding 6 log cycles after the first week of storage. A similar growth pattern was observed for psychrophilic bacteria, regardless of the PEF process temperature (Bermudez-Aguirre et al., 2011). In addition, a shelf-life study carried out by Odriozola-Serrano, Bendicho-Porta, \& Martin-Belloso (2006) where whole raw milk was subjected to PEF (35.5 kV/cm, $1000 \mu \mathrm{s}, 111 \mathrm{~Hz}$ ) in a continuous flow system $(60 \mathrm{ml} / \mathrm{min})$ showed that after eight days of storage, PEF-treated milk was found to contain similar levels of mesophilic aerobic microorganisms as milk which had been treated with thermal pasteurisation $(P>0.05)$.

Other researchers have reported US to have no effect on the levels of yeasts and moulds in milk. In an investigation carried out by Engin and Karagul-Yuceer (2012), no significant difference was found between the levels of yeasts and moulds in US treated (20 $\left.\mathrm{kHz}, 5^{\circ} \mathrm{C}, 75 \mathrm{~W}, 15 \mathrm{~min}\right)$ milk and raw milk $(P>0.05)$. In this study the effect of US on Staphylococcus sp. and E. coli were also assessed, and it was determined that under the specified conditions these microorganisms were reduced by 0.8 and 1.15 log cycles, respectively. A separate study by Herceg, Jambrak, Lelas, \& Thagard (2012) examined the inactivation of $S$. aureus and E. coli in raw whole fat (4\%) cow's milk immediately following 
treatment with US $(20 \mathrm{kHz}, 120 \mu \mathrm{m})$. It was determined that after treatment with US for 12 mins at $60^{\circ} \mathrm{C}, S$. aureus and E. coli were reduced by 1.5 and 3.1 log cycles, respectively. However, in the present study, where sonication was only applied for approximately 2 mins, S. aureus was found to be reduced by 1.4 and 2.7 log cycles following treatment with $\mathrm{MTS} / \mathrm{PEF}$ at respective temperatures of $37^{\circ} \mathrm{C}$ and $55^{\circ} \mathrm{C}$, immediately following processing. The reduction of $E$. coli as a single microorganism was not quantified in the present study, but the levels of Enterobacteriaceae were reduced by 3.9 and 3.63 log cycles following treatment with $\mathrm{MTS} / \mathrm{PEF}$ at $37^{\circ} \mathrm{C}$ and $55^{\circ} \mathrm{C}$, respectively. The levels of inactivation observed in the current study were achieved using a lower amplitude of US (27.9 $\mu$ m compared to 120 $\mu \mathrm{m})$, and a shorter treatment time (c. 2.1 mins). Taking into consideration the inactivation of S. aureus, it appears that although ultrasound alone caused up to 1.49 log cycles of inactivation (Herceg, Jambrak, Lelas, \& Thagard, 2012) under sonication conditions different (i.e. higher amplitude, higher treatment temperature) to those applied in the present study, greater inactivation of $S$. aureus was achieved (c. $2.7 \log$ cycles at $\left.55^{\circ} \mathrm{C}\right)$ in the current study when MTS/PEF was applied in combination. This suggests that either the addition of (i) pressure or (ii) PEF resulted in an increase in the antimicrobial efficacy of ultrasound.

A shelf-life study by Juraga, Salamon, Herceg, \& Jambrak, (2011) using whole fat (4\%) cow's milk showed that after five days of refrigeration, the levels of Enterobacteriae were reduced by 0.2, 2.7 and 3.1 log cycles when compared to raw milk following treatment with US $(20 \mathrm{kHz}, 120 \mu \mathrm{m})$ for 6,9 and 12 mins, respectively. These reductions were increased to 2.12, 4.63 and 3.05 log cycles when US was combined with heat $\left(60^{\circ} \mathrm{C}\right)$. The inactivation levels of Enterobacteriaceae observed in the present study were found to be far greater (a minimum of 3.2 log cycles) than those reported by Juraga, Salamon, Herceg, \& Jambrak, (2011), even though a lower amplitude level was used in our study (27.9 $\mu \mathrm{m})$, and lower temperatures also $\left(37^{\circ} \mathrm{C}\right.$ and $\left.55^{\circ} \mathrm{C}\right)$. This shows the benefits of combining ultrasound 
with pressure and mild heat (i.e. MTS), and also the increased levels of inactivation which can be achieved when MTS and PEF technologies are combined.

A publication by Villamiel and de Jong (2000) discussed the effect of US (20 kHz) on the viability of Pseudomonas fluorescens in raw cow's milk following sonication in a continuous flow system. Reductions of $0.6,0.8$ and 3.1 log cycles were observed, but temperatures of $43.1^{\circ} \mathrm{C}, 49^{\circ} \mathrm{C}$ and $61.6^{\circ} \mathrm{C}$ were applied, respectively, in order to achieve these levels of inactivation. Experiments previously carried out in our laboratory using $P$. fluorescens showed after subjecting this microorganism to treatment with either PEF or a combination of US/PEF, some $P$. fluoresecens cells were not killed but merely sub-lethally injured (unpublished data). This may explain why, in the present study, the levels of pseudomonads reached such high levels (c. 7 logs) after 21 days following treatment with $\mathrm{MTS} / \mathrm{PEF}$ at $37^{\circ} \mathrm{C}$ and $55^{\circ} \mathrm{C}$. Milk which had undergone thermal pasteurisation contained only c. 1 log of pseudomonads after 21 days, showing that thermal pasteurisation kills this microorganism without sub-lethally injuring these bacterial cells. In addition, a study by Craven et al. (2008) showed that pseudomonads could be reduced by $>5$ log cycles following treatment with PEF (31 kV/cm) and mild heat of up to $55^{\circ} \mathrm{C}$. In the present study, lower inactivation values of pseudomonads were recorded for MTS/PEF under our experimental conditions, but it should be noted that the temperature did not exceed $40^{\circ} \mathrm{C}$ during PEF treatment.

In the study by Chouliara, Georgogianni, Kanellopoulou, \& Kontominas (2010), psychrotrophic bacteria were also quantified. On day 0, raw milk which had not been subjected to sonication contained $3.3 \log$ CFU/ml psychrotrophic bacteria, but these levels were reduced to 3.2, 2, 2.2 and 1.9 following 2, 4, 8 and 16 mins of sonication, respectively (24 kHz, amplitude not specified). After eight days, milk which had been sonicated for 16 mins contained significantly fewer psychrotrophic bacteria than all other milk samples 
$414(P<0.05)$. However, it should be noted that these milk samples were not subjected to 415 sonication in a continuous-flow system. In the current study, levels of psychrotrophic bacteria reached c. $4 \log \mathrm{CFU} / \mathrm{ml}$ in milk treated with $\mathrm{MTS} / \mathrm{PEF}$ at $37^{\circ} \mathrm{C}$ and $55^{\circ} \mathrm{C}$ after 21 days of

417 storage at $4^{\circ} \mathrm{C}$. This increase in microbial levels may have been due to the presence of some

418 Gram-positive thermoduric bacteria and spores, which are known to have the potential to survive thermal pasteurisation and/or PEF and ultrasound processing (Shamsi, Versteeg, Sherkat, \& Wan, 2008). It may be the case that a greater number of thermoduric bacteria are killed by thermal pasteurisation than by processing with manothermosonication and PEF, but further investigation would be required in order to determine the exact nature of the inactivation of such microorganisms. Some preliminary studies carried out in this laboratory have shown that treatment with MTS/PEF caused sub-lethal injury of E. coli K12 and Ps. fluorescens (data not shown), and it may be the case that other microorganisms are merely injured following treatment with these non-thermal technologies, and are not actually 'killed'. Nonetheless, the present study shows that inactivation of psychrotrophic bacteria is achievable by MTS/PEF.

\section{Conclusion}

The present study has shown that treating milk with MTS/PEF can inhibit microbial growth without the use of excessive heat, such as the temperatures employed during thermal pasteurisation. Although conventional pasteurisation appears to be the most effective method of prolonging the shelf-life of milk, the results for microbial inactivation following treatment with MTS/PEF are promising. However, further optimisation of processing conditions would be required in order to improve the microbiological quality of milk treated with MTS/PEF so that microbial content is on a par with those typical of thermally pasteurised milk. Also, it would be worthwhile to investigate the efficacy of these technologies for control of other 
438 pathogens associated with raw milk, such as Listeria monocytogenes, Yersinia enterocolitica 439 and Campylobacter jejuni.

\section{Acknowledgements}

441 This work was supported by SMARTMILK, a 2 year R\&D project funded by the Seventh 442 Framework Programme of the EC under the "Research for SMEs" sub-programme. Grant 443 agreement No. 261591. The authors would also like to thank Lyons Research Farm 444 (Newcastle, Co. Dublin) for supplying the milk used throughout this study. 


\section{Literature cited}

447 Aronsson, K., Borch, E., Stenlof, B., \& Ronner, U. (2004) Growth of pulsed electric field exposed Escherichia coli in relation to inactivation and environmental factors. International Journal of Food Microbiology, 93 (1), 1-10.

Bendicho, S., Barbosa-Canovas, G.V., \& Martin, O. (2002) Milk processing by high intensity pulsed electric fields. Trends in Food Science and Technology, 13, 195-204.

Bermudez-Aguirre, D., Mawson, R., Versteeg, K., \& Barbosa-Canovas, G.V. (2009) Composition properties, physicochemical characteristics and shelf-life of whole milk after thermal and thermo-sonication treatments. Journal of Food Quality, 32 (3), 283302.

Bermudez-Aguirre, D., Fernandez, S., Esquivel, H., Dunne, P.C., \& Barbosa-Canovas, G. V. (2011) Milk processed by pulsed electric fields: Evaluation of microbial quality, physicochemical characteristics, and selected nutrients at different storage conditions. Journal of Food Science, 76 (5), S289-S299.

Chouliara, E., Georgogianni, K.G., Kanellopoulou, N., \& Kontominas, M.G. (2010) Effect of ultrasonication on microbiological, chemical and sensory properties of raw, thermized and pasteurized milk. International Dairy Journal, 20 (5), 307-313.

Craven, H.M., Swiergon, P., Ng, S., Midgely, C., Versteeg, C., Coventry, M.J., \& Wan, J. (2008) Evaluation of pulsed electric field and minimal heat treatments for inactivation of pseudomonads and enhancement of milk shelf-life. Innovative Food Science \& Technologies, 9 (2), 211-216. 
Cserhalmi, Z., Sass-Kiss, A., Toth-Markus, M., \& Lechner, N. (2006) Study of pulsed electric field treated citrus juices. Innovative Food Science \& Emerging Technologies, 7, 49-54.

Devlieghere, F., Vermeiren, L., \& Debevere, J. (2004) New preservation technologies: Possibilities and limitations. International Dairy Journal, 14 (4), 273-285.

Dolatowski, Z.J., Stadnik, J., \& Stasiak, D. (2007) Applications of ultrasound in food technology. Acta Sci. Pol., Technol. Aliment., 6 (3), 89-99.

Engin, B., \& Karagul-Yuceer, Y. (2012) Effects of ultraviolet light and ultrasound on microbial quality and aroma-active components of milk. Journal of the Science of Food and Agriculture, 92, 1245-1252.

Hamilton W.A., \& Sale, A.J.H. (1967) Effects of high electric fields on microorganisms. II. Mechanism of action of the lethal effect. Biochimica et Biophysica Acta, 87, 102-107

Herceg, Z., Jambrak, A.R., Lelas, V., \& Thagard, S.M. (2012) The effect of high intensity ultrasound treatment on the amount of Staphylococcus aureus and Escherichia coli in milk. Food Technology and Biotechnology, 50 (1), 46-52.

Juraga, E., Salamon, B.S., Herceg, Z., \& Jambrak, A.R. (2011) Application of high intensity ultrasound treatment on Enterobacteriae count in milk. Mljekarstvo, 61 (2), 125-134.

Manas, P., \& Pagan, R. (2005) Microbial inactivation by new technologies of food preservation. Journal of Applied Microbiology, 98 (6), 1387-1399.

Noci, F., Walkling-Ribeiro, M., Cronin. D.A., Morgan, D.J., \& Lyng, J.G. (2009) Effect of thermosonication, pulsed electric field and their combination on inactivation of Listeria innocua in milk. International Dairy Journal, 19, 30-35. 
489

490

491

492

493

494

495

496

497

498

499

500

501

502

503

504

505

506

507

508

509

510

511

Odriozola-Serrano, I., Bendicho-Porta, S., \& Martin-Belloso, O. (2006) Comparative study on shelf life of whole milk processed by high-intensity pulsed electric field or heat treatment. Journal of Dairy Science, 89, 905-911.

Pereda, J., Ferragut, V., Quevedo, J.M., Guamis, B., \& Trujillo, A.J. (2009) Heat damage evaluation in ultra-high pressure homogenized milk. Food Hydrocolloids, 23 (7), 1974-1979.

Piyasena, P., Mohareb, E., \& McKellar, R.C. (2003) Inactivation of microbes using ultrasound: a review. International Journal of Food Microbiology, 87 (3), 207-216.

Salvia-Trujillo, L., Morales-de la Pena, M., Rojas-Grau, M.A., \& Martin-Belloso, O. (2011) Microbial and enzymatic stability of fruit juice-milk based beverages treated by high intensity pulsed electric fields or heat during refrigerated storage. Food Control, 22 (10), 1639-1646.

Sampedro, F., Geveke, D.J., Fan, X., Rodrigo, D., \& Zhang, Q.H. (2009) Shelf-life study of an orange juice-milk based beverage after PEF and thermal processing. Journal of Food Science, 74 (2), S107-S112.

Sepulveda, D.R., Gongora-Nieto, M.M., Guerrero, J.A., \& Barbosa-Canovas, G.V. (2009) Shelf life of whole milk processed by pulsed electric fields in combination with PEFgenerated heat. LWT- Food Science and Technology, 42 (3), 735-739.

Shamsi, K., Versteeg, C., Sherkat, F., \& Wan, J. (2008) Alkaline phosphatase and microbial inactivation by pulsed electric field in bovine milk. Innovative Food Science \& Emerging Technologies, 9, 217-223.

Villamiel, M., \& de Jong, P. (2000) Inactivation of Pseudomonas fluorescens and Streptococcus thermophilus in Trypticase ${ }^{\circledR}$ Soy Broth and total bacteria in milk by 
continuous-flow ultrasonic treatment and conventional heating. Journal of Food Engineering, 45 (3), 171-179.

514

515

516

Walkling-Ribeiro, M., Noci, F., Cronin, D.A., Lyng, J.G., \& Morgan, D.J. (2008) Inactivation of Escherichia coli in a tropical fruit smoothie by a combination of heat and pulsed electric fields. Journal of Food Science, 73 (8), M395-M399.

Walkling-Ribeiro, M., Noci, F., Cronin, D.A., Lyng, J.G., \& Morgan, D.J. (2009a) Shelf life and sensory evaluation of orange juice after exposure to thermosonication and pulsed electric fields. Food and Bioproducts Processing, 87 (2), 102-107.

Walkling-Ribeiro, M., Noci, F., Riener, J., Cronin, D.A., Lyng, J.G., \& Morgan, D.J. (2009b) The impact of thermosonication and pulsed electric fields on Staphylococcus aureus inactivation and selected quality parameters in orange juice. Food and Bioprocess Technology, 2 (4), 422-430.

Walkling-Ribeiro, M., Noci, F., Cronin, D.A., Lyng, J.G., \& Morgan, D.J. (2010) Shelf life and sensory attributes of a fruit smoothie-type beverage processed with moderate heat and pulsed electric fields. LWT- Food Science and Technology, 43 (7), 1067-1073.

Walkling-Ribeiro, M., Rodriguez-Gonzalez, O., Jayaram, S., \& Griffiths, M.W. (2011) Microbial inactivation and shelf life comparison of 'cold' hurdle processing with pulsed electric fields and microfiltration, and conventional thermal pasteurisation in skim milk. International Journal of Food Microbiology, 144 (3), 379-386.

Yeom, H.W., Streaker, C.B., Zhang, Q.H., \& Min, D.B. (2000) Effects of pulsed electric fields on the quality of orange juice and comparison with heat pasteurization. Journal of Agricultural and Food Chemistry, 48 (10), 4597-4605. 
536

Figure 1: TVC levels of various milk samples over a 21-day period; Raw milk (white bar), $\mathrm{MTS} / \mathrm{PEF}$ at $37^{\circ} \mathrm{C}$ (grey bar), $\mathrm{MTS} / \mathrm{PEF}$ at $55^{\circ} \mathrm{C}$ (striped bar) and thermally pasteurised (black bar). Data= mean \pm S.D. $(n=3)$.

Figure 2: Yeast and mould levels of various milk samples over a 21-day period; Raw milk (white bar), $\mathrm{MTS} / \mathrm{PEF}$ at $37^{\circ} \mathrm{C}$ (grey bar), MTS/PEF at $55^{\circ} \mathrm{C}$ (striped bar) and thermally pasteurised (black bar). Data= mean \pm S.D. $(n=3)$.

Figure 3: S. aureus content of various milk samples over a 21-day period; Raw milk (white bar), $\mathrm{MTS} / \mathrm{PEF}$ at $37^{\circ} \mathrm{C}$ (grey bar), $\mathrm{MTS} / \mathrm{PEF}$ at $55^{\circ} \mathrm{C}$ (striped bar) and thermally pasteurised (black bar). Data= mean \pm S.D. $(n=3)$.

Figure 4: Enterobacteriaceae content of various milk samples over a 21-day period; Raw milk (white bar), $\mathrm{MTS} / \mathrm{PEF}$ at $37^{\circ} \mathrm{C}$ (grey bar), MTS/PEF at $55^{\circ} \mathrm{C}$ (striped bar) and thermally pasteurised (black bar). Data= mean \pm S.D. $(n=3)$.

Figure 5: Lactic acid bacteria levels of various milk samples over a 21-day period; Raw milk (white bar), MTS/PEF at $37^{\circ} \mathrm{C}$ (grey bar), MTS/PEF at $55^{\circ} \mathrm{C}$ (striped bar) and thermally pasteurised (black bar). Data= mean \pm S.D. $(n=3)$.

Figure 6: Pseudomonads content of various milk samples over a 21-day period; Raw milk (white bar), MTS/PEF at $37^{\circ} \mathrm{C}$ (grey bar), MTS/PEF at $55^{\circ} \mathrm{C}$ (striped bar) and thermally pasteurised (black bar). Data= mean \pm S.D. $(n=3)$.

Figure 7: Psychrotrophic bacteria content of various milk samples over a 21-day period; Raw milk (white bar), MTS/PEF at $37^{\circ} \mathrm{C}$ (grey bar), MTS/PEF at $55^{\circ} \mathrm{C}$ (striped bar) and thermally pasteurised (black bar). Data $=$ mean \pm S.D. $(n=3)$. 
558 Figure 1:

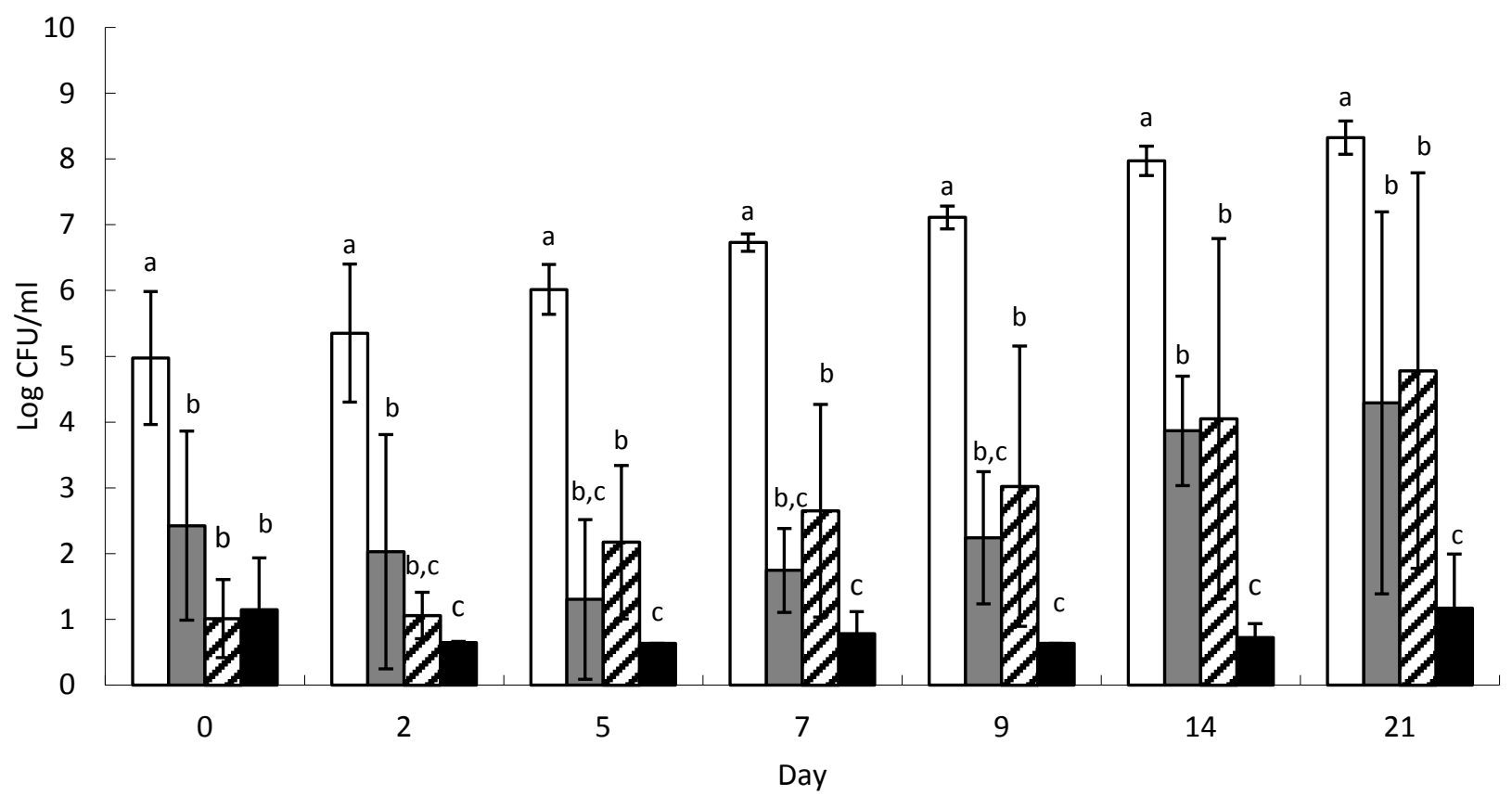

559

560

561 
562 Figure 2:

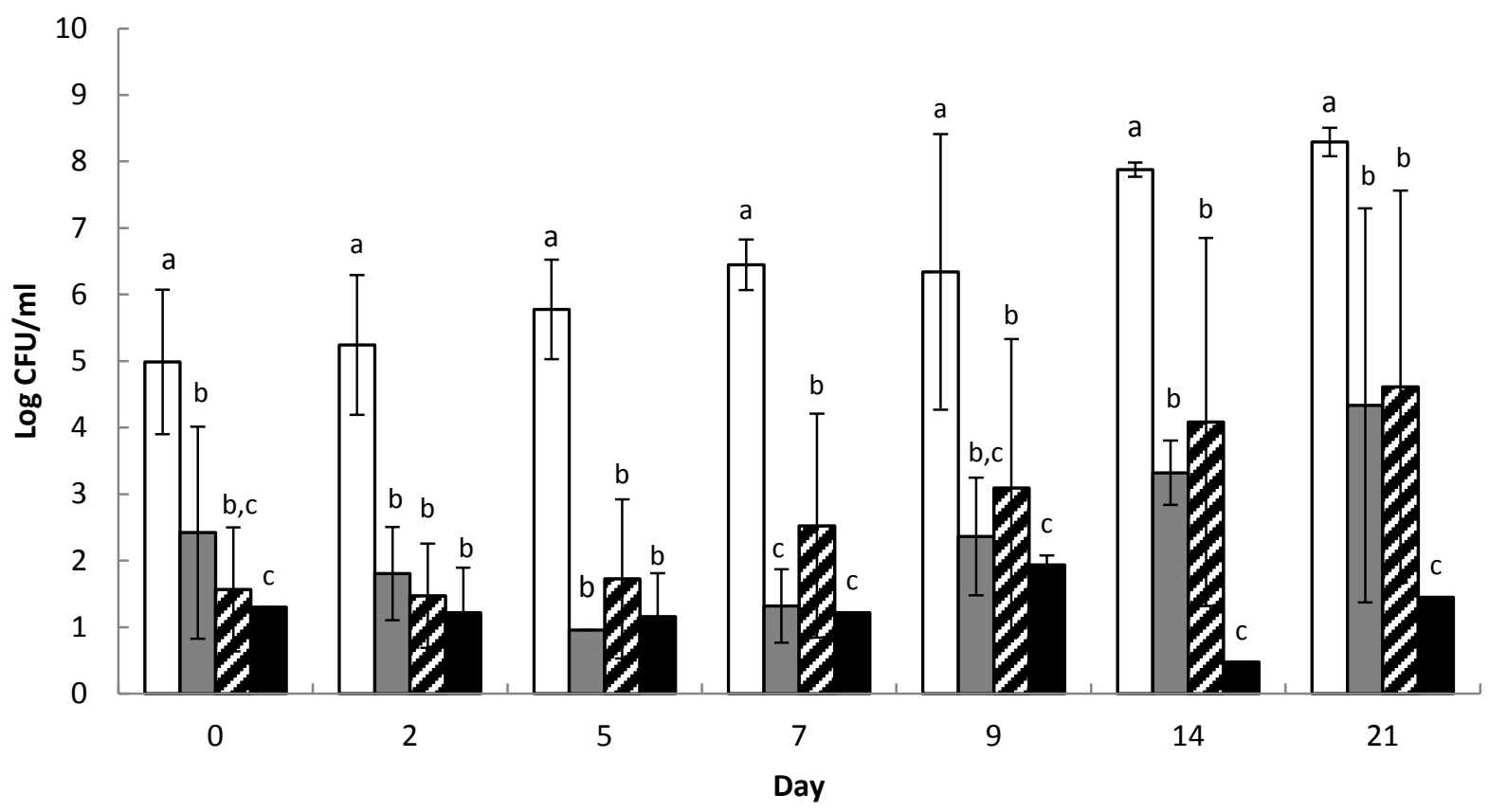

563 
565 Figure 3:

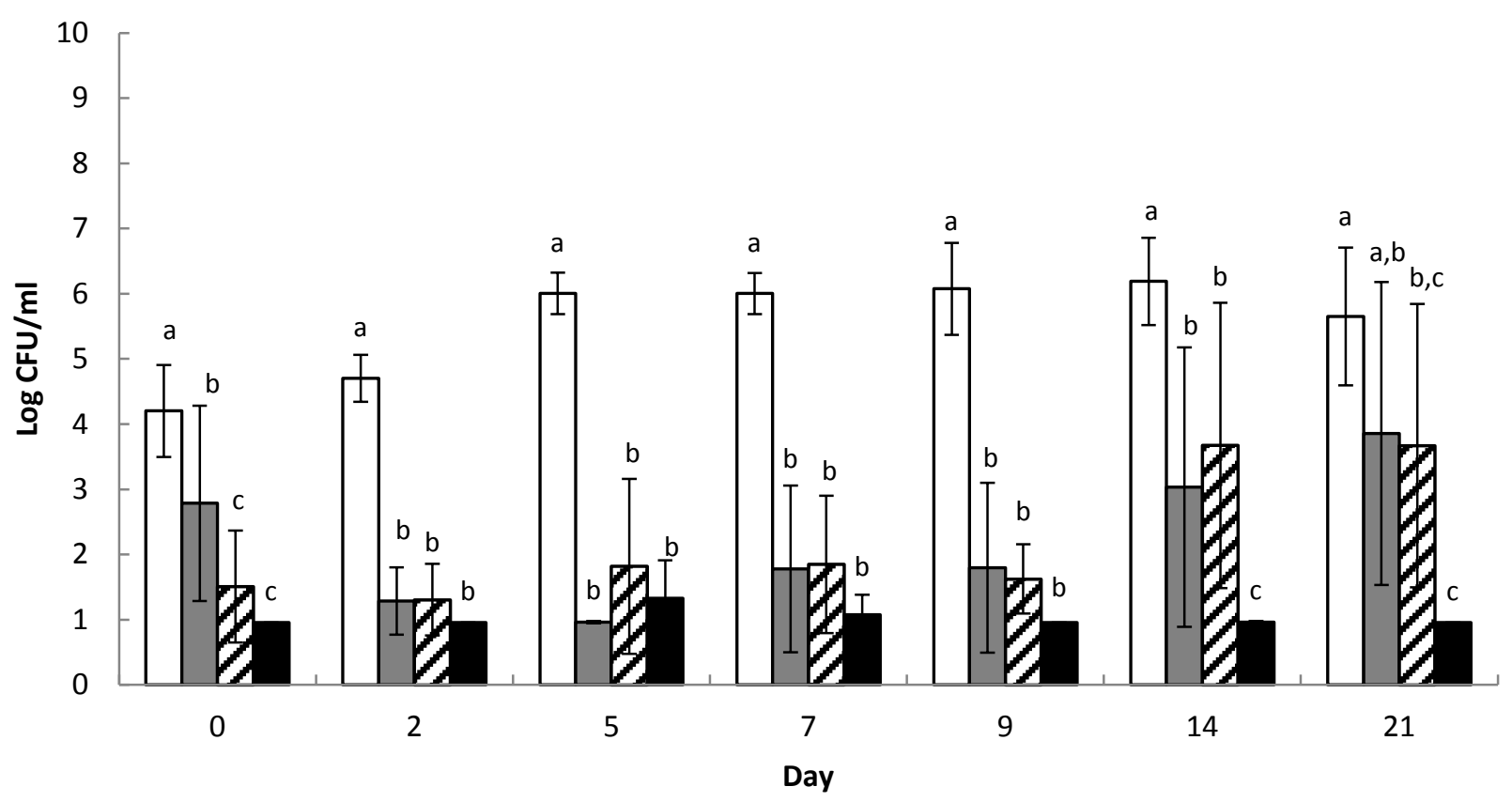

566

567 
568 Figure 4:

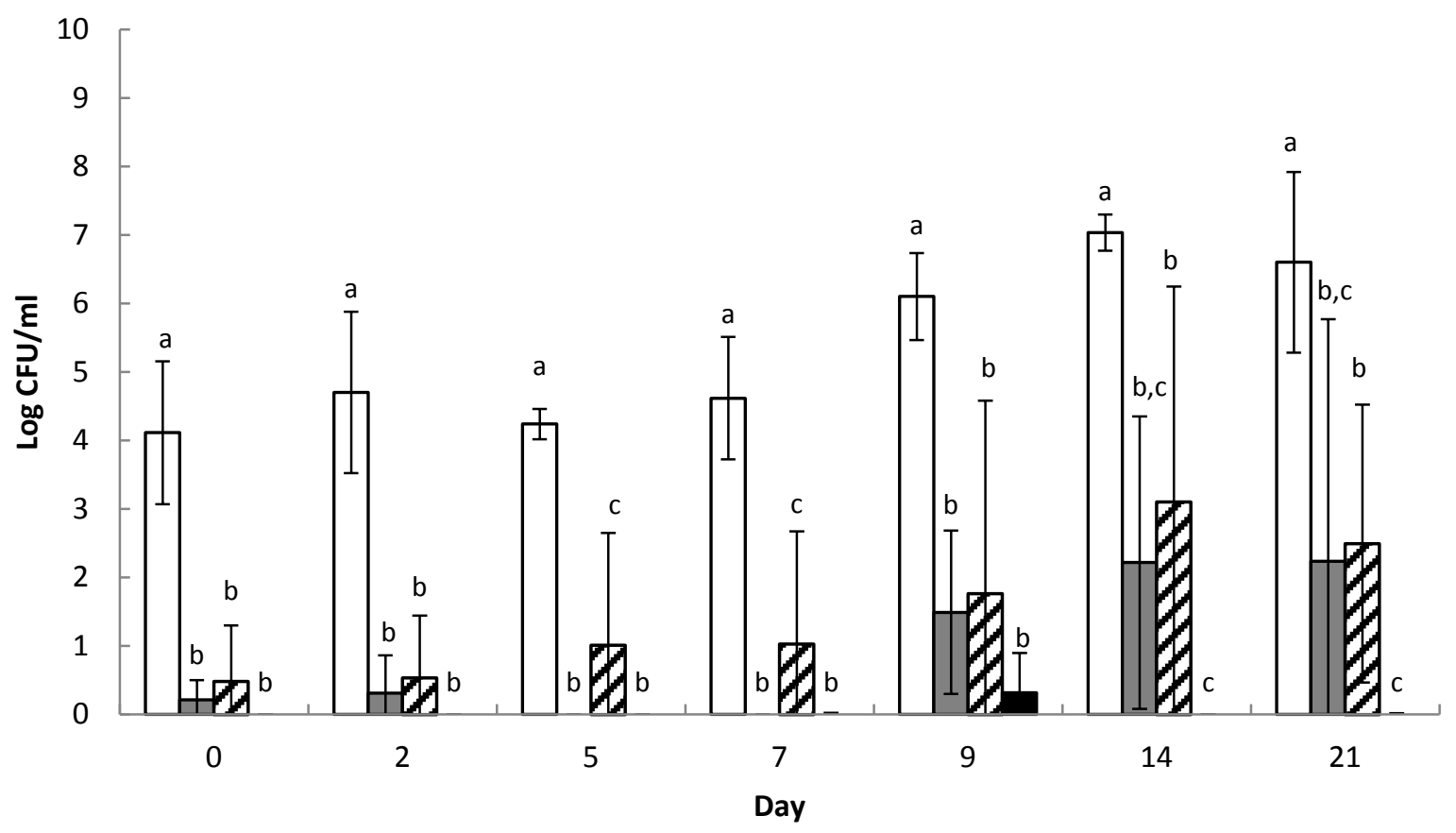

569

570 
571 Figure 5:

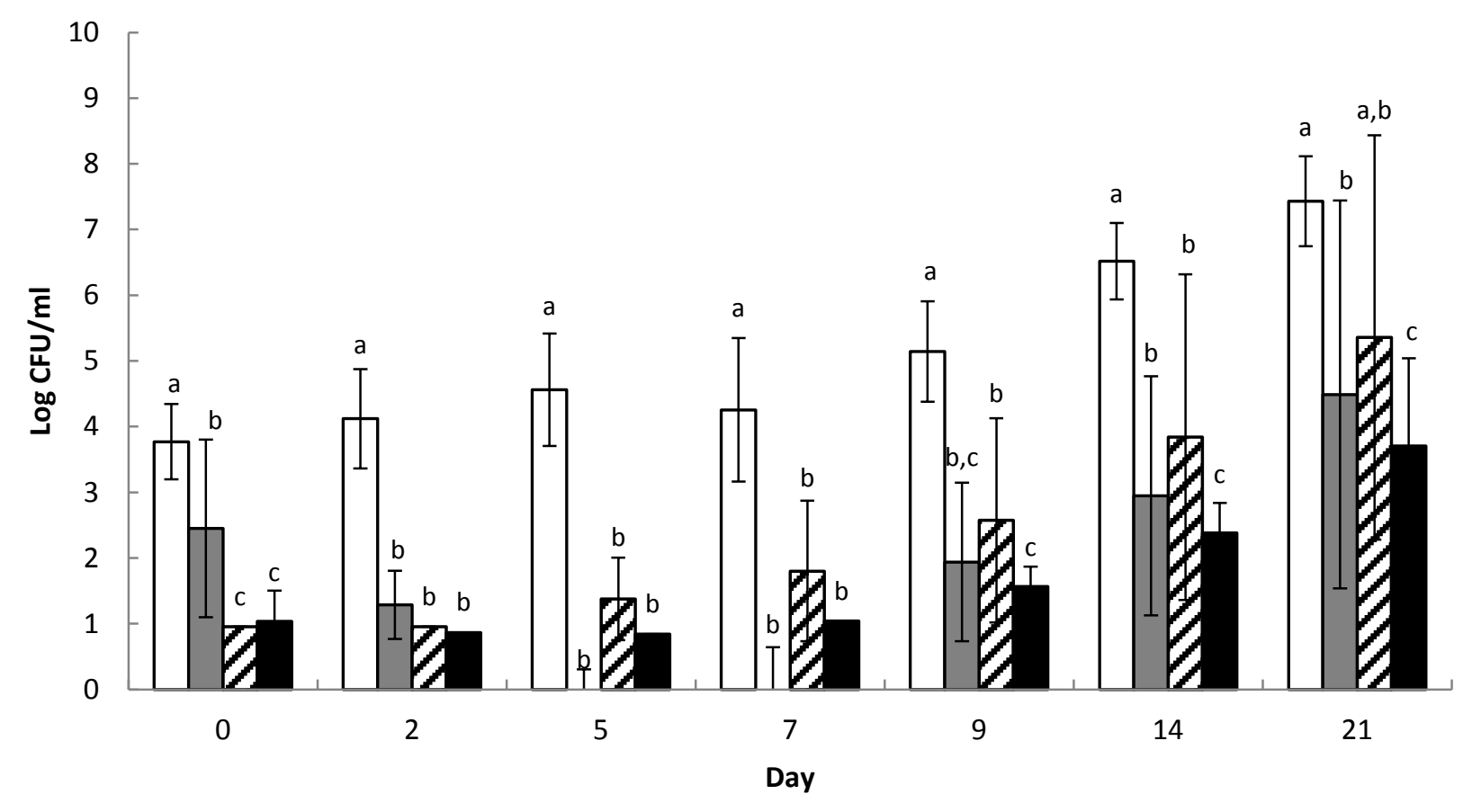

572

573 
574 Figure 6:

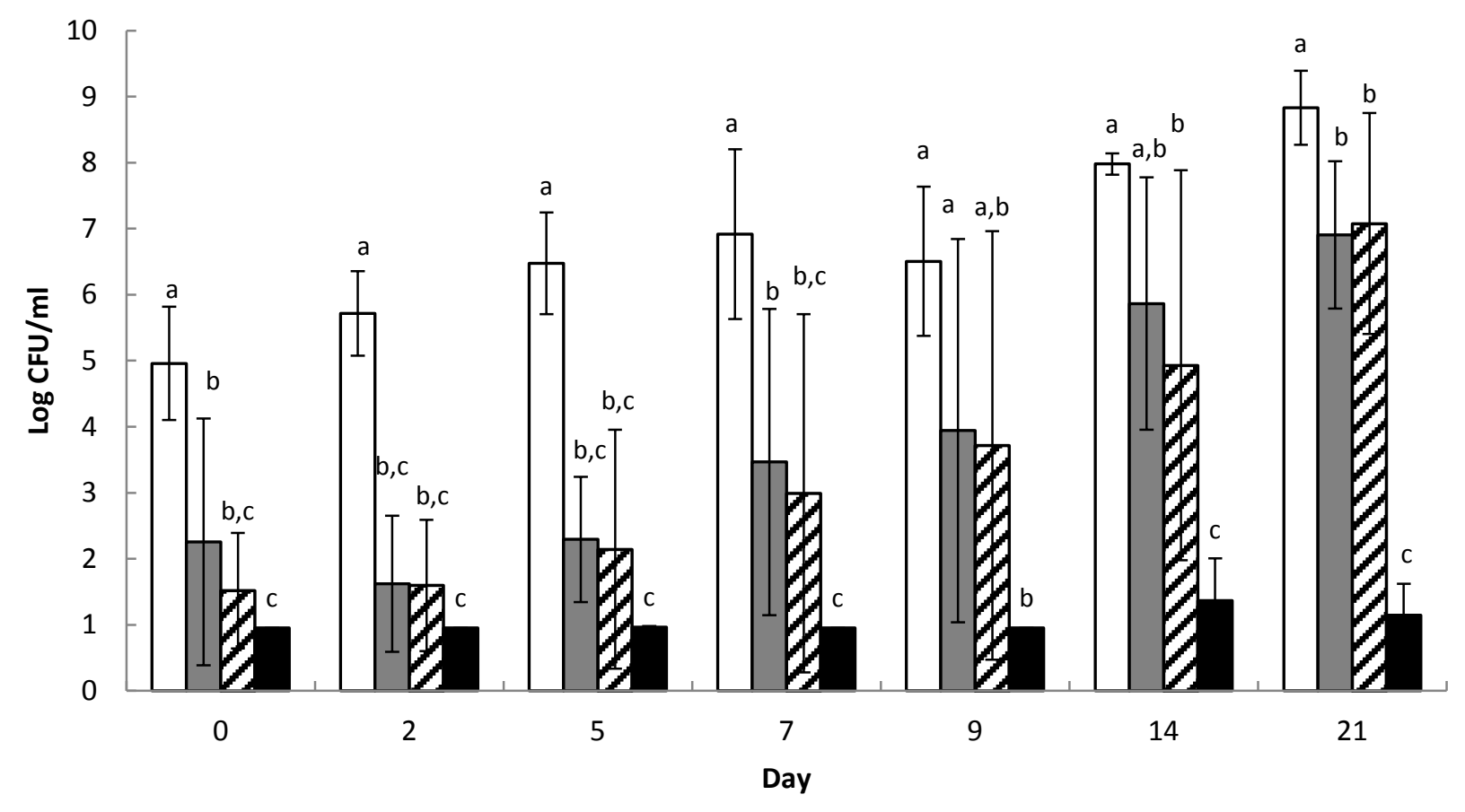

575

576 
$577 \quad$ Figure 7:

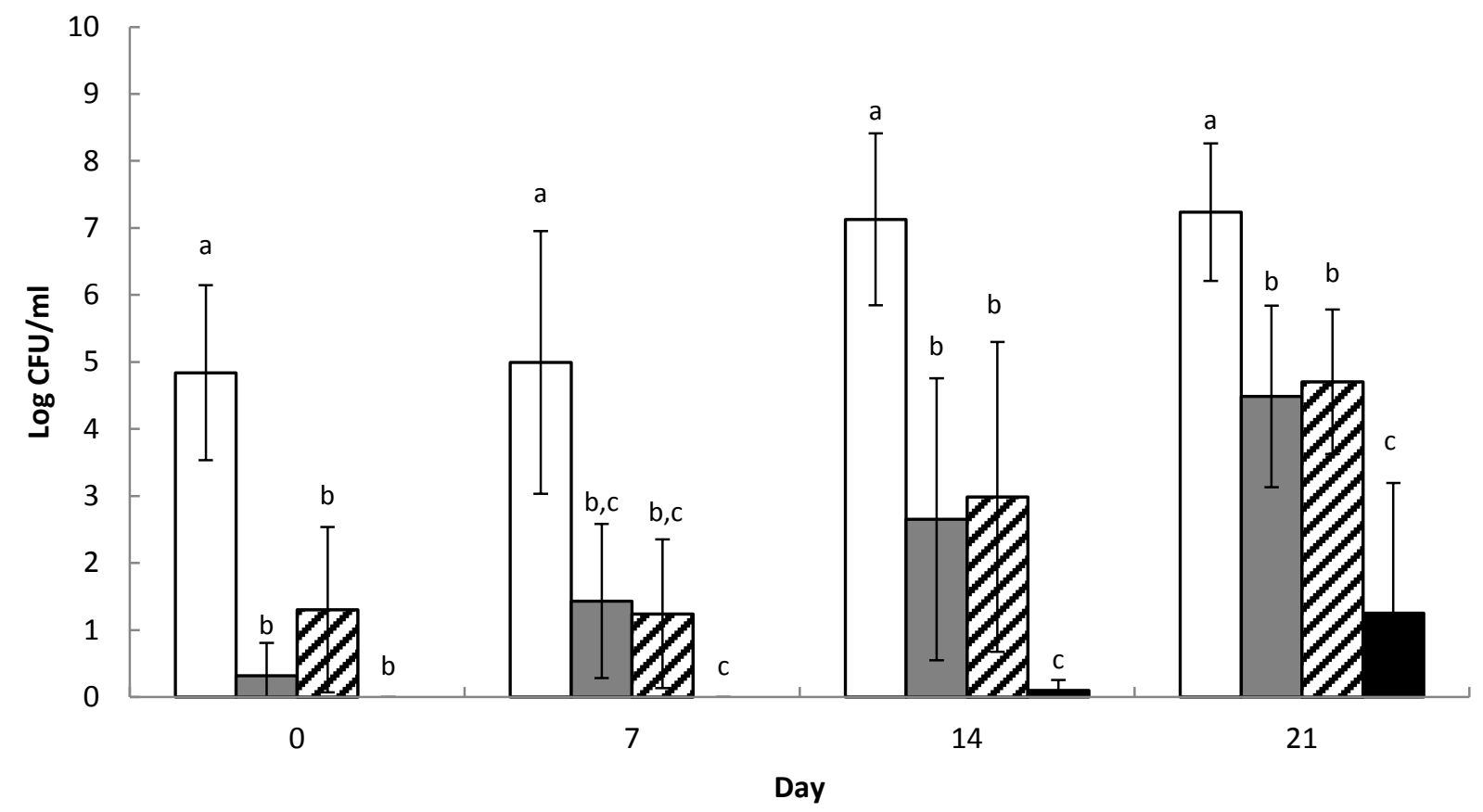

578

579 